\title{
Measurement Of Company Performance With Approach Balanced Score Study Case: Regional Drinking Water Company
}

\author{
Kurniati Karim ${ }^{1 *}$, Dennis Rydarto Tambunan ${ }^{2}$, Nirta Vera Yustanti \\ ${ }^{3}$, Heru Kreshna Reza ${ }^{4}$, Melly Susanti ${ }^{5}$
${ }^{1}$ Deaprtement of Management, Faculty of Economic, STIE Sakti Alam Sungai Penuh Jambi, Indonesia
${ }^{4}$ Department of Accounting, Faculty of Economics and Business, Esa Unggul University, Indonesia
${ }^{5}$ Department of Accounting, Faculty of Economic, Dehasen Bengkulu University, Indonesia
* Corresponding author:
Email: atiekkarim299@gmail.com \\ ${ }^{2,3}$ Department of Management, Faculty of Economic, Dehasen Bengkulu University, Indonesia
}

\begin{abstract}
.
Performance is a process carried out in achieving a result for each company or organization in the stage of providing services or products to customers within a certain period of time in accordance with their duties and functions. This study aims to conduct and see the overall organizational picture of the performance assessment of the Regional Water Company (PDAM) of Sungai Penuh Jambi City using the Balanced Score Card approach. viewed from four perspectives, namely: financial perspective, customer perspective, internal business perspective, and learning and growth perspective. From the results of the research on the Performance Measurement of Regional Drinking Water Companies (PDAM) of Sungai Penuh Jambi City using the Balanced Scorecard approach from a financial perspective through the current ratio, profit margin, operation ratio, return on investment, it shows that the company's financial performance is in good condition despite a decline in sales in 2019 For performance measurement based on customer perspective from customer acquisition, customer retention, customer satisfaction, customer satisfaction can be said to be good, although customer satisfaction that the Regional Drinking Water Company (PDAM) of Sungai Penuh Jambi City in 2020 can be said to be not good. Furthermore, the correlation/correlation of performance based on the perspective of internal business processes on the motivation variable, power alignment, has an influence level of $50.9 \%$ with a significance level of $<5 \%$ or $0 \%$, but for training it has a significance level. below $5 \%$ or equal to $0 \%$. The performance based on the learning and growth perspective on employee satisfaction, employee retention, productivity, contributes positively to the company's economic improvement.
\end{abstract}

Keywords: Balanced Scorecard, Financial Perspective, Customer Perspective, Internal Business Perspective, Learning and Growth.

\section{INTRODUCTION}

One of the strategic steps taken to determine the potential and capabilities of the company is to perform a performance measurement system. This performance measurement is carried out to evaluate the ability and performance of the company. Many [6]. the benefits that can be taken from the results of the company's performance 
measurement such as determining business development strategies, reward strategies, human resource development strategies and so on. In addition, performance appraisal or measurement is one of the important factors in the company besides being used to assess the company's success. Performance appraisal can also be used as a basis for evaluating performance results from the past period [11]. Traditional performance measurement emphasizes the financial aspect, because it is easier to implement so that the personal performance benchmark is measured in terms of the financial aspect only [6].

Balanced Scorecard is a method of measuring company performance. The Balanced Score Card has four perspectives, namely; financial perspective, customer perspective, internal business process perspective and learning and growth perspective. The four perspectives are expected to provide a new perspective on performance measurement so that later the measurement results can be used to determine short-term and long-term corporate strategies. Thus the Balanced Scorecard can be used as a tool to implement the strategy [4]. The Balanced Scorecard can align various functions (divisions, departments, sections) so that all decisions and activities within each of these functions can achieve company goals [5]. According to Helfert, company performance is a view of the complete state of the company during a certain period of time, is a result or achievement that is influenced by the company's operational activities in utilizing its resources [9]. Performance is the result of work in quality and quantity achieved by an employee in carrying out his duties in accordance with the responsibilities given to him [10]. Performance measurement is needed to assess the level of deviation between actual performance and expected performance. Thus, it is expected that actual performance will go hand in hand with expected performance [7]

Performance measurement with the Balanced Score Card is an alternative performance measurement based on four main things, namely finance, customers, internal business processes, learning and growth. The advantage of using the Balanced Score Card is that the Balanced Scorecard approach seeks to translate the company's mission and strategy into goals and measurements viewed from four perspectives, namely finance, customers, internal business processes, learning and growth. Balanced Scorecard can help public companies in controlling finances [2] and Balanced Scorecard can also measure company performance [1]. A public company is a company established with the aim of providing services to the public. This causes public companies to measure their success through effectiveness and efficiency in providing services to the community. With the Balanced Scorecard, the company can also anticipate weaknesses by taking measurements from each perspective, so that the weaknesses mentioned can be reduced [3] including the Regional Drinking Water Company (PDAM). The company is faced with determining a strategy in managing its business. The determination of the strategy will be used as the basis and framework for realizing the work objectives that have been determined by management. 
Therefore, a tool is needed to measure performance so that it is known how far the strategies and targets that have been determined and achieved by PDAM. According to Kaplan, et al. Balanced Score Card is a framework, a language that communicates vision, mission, and strategy to all employees about the key determinants of current and future success [5]. The Method Balanced Score Card provides a comprehensive framework for translating the vision into strategic objectives. Comprehensive strategic goals can be formulated because the method Balanced Score Card uses four perspectives: finance, customers, internal business processes, learning and growth. According to Warindrani, the Balanced Score Card has advantages that make the measurements significantly different from traditional performance measurements [10]. Basically the four perspectives of the Balanced Score Card, namely finance, customers, internal processes and learning/growth must be integrated with each other to support the strategic plan that has been previously determined by the company [11]. According to Mulyadi et al. Balanced Scorecard uses a financial perspective because the performance assessment is an overview of the economic consequences that have been carried out [6]. Financial performance assessment can be used as an indicator of whether the company's strategy, implementation and decisions are based on the percentage of average revenue growth, average sales growth in the target market. The financial ratios used are Kaplan et al are; Return On Investment (ROI), Profit margin, Operating Ratio is operating expenses divided by net sales and expressed in percent. Customer Perspective The, company is expected to create a market segmentation and determine the most likely target market to be targeted according to the company's capabilities, resources and long-term plans [6] is Internal Business Process Perspective and Learning and Growth Perspective.

PDAM in Sungai Penuh Jambi City is a company engaged in the service of providing clean water. One of the goals of the establishment of PDAM is to meet the community's need for clean water, including the provision, development of facilities and infrastructure services as well as clean water distributors, while the other goal is to participate in developing the economy to support regional development by expanding employment opportunities and seeking profit as the main source of financing for local residents. area. To measure the performance of Regional Drinking Water Companies (PDAMs) in Sungai Penuh Jambi City, a performance measurement system is needed that not only measures financial aspects but also considers non-financial aspects such as customers, internal business processes, as well as learning and growth. This performance measure is called the Balanced Scorecard. The management is left entirely to the Regional Government as a monopolistic company, PDAM is expected to be a public servant at the same time as well as to contribute significantly to the Regional Original Revenue (PAD).

The results of the field survey show that PDAM Kota Sungai Penuh Jambi Jambi is known that performance measurement is still conventional and partial. This 
means that PDAM Kota Sungai Penuh Jambi in evaluating organizational performance still separates each aspect of the assessment separately, so that PDAM cannot formulate the right strategy in measuring its performance. PDAM performance measurement is guided by the single LAKIP (Government Agency Performance Accountability Report) instrument [7]. In fact, the performance of government agencies is multidimensional, which means that the performance of government agencies does not have a single indicator that can be used to show the level of success comprehensively, both financially and non-financially. If the performance measurement is only based on the financial aspect, it will cause many weaknesses. This phenomenon makes the performance of PDAM PDAM Sungai Penuh Jambi only measured from the financial aspect, so it is difficult to know multidimensionally. Therefore, in order to know the multidimensional performance of the organization, the performance measurement model needs to be changed.In this study, we have analyzed the performance measurement of PDAM Kota Sungai Penuh Jambi, the problem discussed in this study is how to measure performance based on the Balanced Scorecard at the Regional Water Company (PDAM) of Sungai Penuh Jambi City. This study aims to analyze how the performance of the Regional Water Supply Company (PDAM) of Sungai Penuh Jambi City by using the approach Balanced Scorecard.

\section{METHODS}

Ttype of research used in this research is descriptive research. According to Sugiyono, descriptive research is a research that aims to provide or describe a situation or phenomenon that is currently happening by using scientific methods to answer actual problems through the calculation of statistical figures, both inferential and parametric. This study uses quantitative methods to examine the effect of the perspective Balanced Score Card on the performance of PDAM Kota Sungai Penuh Jambi. Data collection in this study used secondary and primary data.

\section{Methods of Analysis}

\section{Descriptive Analysis Descriptive}

Analysis is used to describe and describe the research variables according to field conditions. In describing the data, descriptive statistics are used in the form of the average value, frequency, percentage and standard deviation. 2. Quantitative Analysis Quantitative analysis is used to measure PDAM performance based on the perspective of the Balanced Score Card (BSC). The theory used refers to the opinion of Kaplan et al. The quantitative analysis includes;

1. Performance based on financial perspective such as (Current ratio, Profit Margin, Operating Ratio, Return On Investment).

2. Measure Performance based on Customer Perspective, such as (Customer acquisition rate, Customer retention rate, Customer satisfaction level)

3. Performance based on Internal Business Perspective through Learning and Growth, such as (Motivation, power and alignment $=$ Measurement by conducting a 
questionnaire survey to employees, Training $=$ Measurement by conducting a questionnaire survey to employees)

4. Performance based on the Learning and Growth Perspective, such as (Employee satisfaction, employee retention, and employee productivity)

\section{RESULT AND DISCUSSION}

Performance measurement with the approach Balanced Score Card at PDAM Sungai Penuh Jambi is one of the very important factor for a company. The results of performance measurement can be seen in the following explanation;

\section{Financial Perspective}

\section{a. Current Ratio (CR)}

Assessment based on the Current Ratio (CR) can be seen in the following table;

Table1. Current Ratio (CR) of Regional Drinking Water Companies in Sungai Penuh Jambi City

\begin{tabular}{|l|c|c|c|}
\hline Financial Perspective & $\mathbf{2 0 1 8}$ & $\mathbf{2 0 1 9}$ & $\mathbf{2 0 2 0}$ \\
\hline Current asset & 36.532 .684 .219 & 58.585 .857 .548 & 37.349 .254 .773 \\
\hline Current liabilities & 3.451 .513 .539 & 4.543 .990 .528 & 598.415 .103 \\
\hline Current Ratio & $10,58 \%$ & $13,89 \%$ & $62,8742 \%$ \\
\hline
\end{tabular}

Source: Data processed in 2021

Based on the Current Ratio (CR) at the Regional Drinking Water Company (PDAM) of Sungai Penuh Jambi City from the Balanced Score Card, it shows that the performance assessment for the financial perspective has increased. In 2018 it increased to $10.58 \%$ and in 2019 it increased to $13.89 \%$. And in 2020 it also increased by $62.87 \%$, due to the results of product sales obtained by the company through calculations using the ROI formula. Thus, according to the calculation of ROI, the company can see the ability of the capital invested in the overall assets that generate net profit in the company, so that the ability of the capital invested in the Regional Water Company of Sungai Penuh Jambi City can be said to be good.

\section{b. Profit margin}

Assessment based on profit margin can be seen in the following table;

Table 2.Assessment Profit margin PDAM Sungai Penuh Jambi City

\begin{tabular}{|l|c|c|c|}
\hline Financial Perspective & $\mathbf{2 0 1 8}$ & $\mathbf{2 0 1 9}$ & $\mathbf{2 0 2 0}$ \\
\hline Profit after tax & 774657576 & 755726835 & $1,117,860,555$ \\
\hline Sales / income & $41,088,748,914$ & $40,267,208,800$ & $51,208,402,300$ \\
\hline Profit Margin & 0.018853277 & 0.018767798 & 0.021829632 \\
\hline
\end{tabular}

Source: Data processed in 2021

In terms of profit margin or profit margin, it shows that operating profit related to sales has increased, profit margin has decreased in 2019 by $0.001 \%(0.0188-0.0189)$ but in 2020 it has increased by $0.003 \%$ Decrease in sales in 2019 caused by delayed delivery of products or goods to consumers. The delay occurred due to the lack of maintenance of transportation equipment and the lack of discipline of employees at the Sungai 
Penuh Jambi City Drinking Water Company (PDAM). Thus, the profit margin for the Regional Water Supply Company of Sungai Penuh Jambi City is considered less good.

\section{c. Operating Ratio}

Assessment based on Operating Ratio can be seen in the following table;

Table 3. Assessment Based on Operating Ratio of PDAM

Kota Sungai Penuh Jambi

\begin{tabular}{|l|c|c|c|}
\hline Financial Perspective & $\mathbf{2 0 1 8}$ & $\mathbf{2 0 1 9}$ & $\mathbf{2 0 2 0}$ \\
\hline Profit after tax & 774657576 & 755726835 & $1,117,860,555$ \\
\hline Sales / income & $41,088,748,914$ & $40,267,208,800$ & $51,208,402,300$ \\
\hline Operation Ratio & 0.018853277 & 0.018767798 & 0.021829632 \\
\hline
\end{tabular}

Source: Data processed in 2021

Operation Ratio shows that operating profit related to sales has increased, but seen from the average profit margin value at the Regional Drinking Water Company (PDAM) of Sungai Penuh Jambi City, it can be said to be good because there is an increase in the operating ratio from 2019 to 2020. It's just that there was a decrease in 2019. The purpose of calculating the profit margin is to find out the value of operating profit related to sales in the company. The decline in sales in 2019 was caused by arrears in payments from consumers.

\section{d. Return On Investment}

Assessment based on Return On Investment can be seen in the following table;

Table 4. Assessment based on Return On Investment can be seen in the following table;

\begin{tabular}{|l|l|l|l|}
\hline Financial Perspective & \multicolumn{1}{|c|}{$\mathbf{2 0 1 8}$} & \multicolumn{1}{|c|}{$\mathbf{2 0 1 9}$} & \multicolumn{1}{|c|}{$\mathbf{2 0 2 0}$} \\
\hline Profit after tax & 874657576 & $35,726,836$ & 111786555 \\
\hline Sales / income & $\begin{array}{l}105705348 \\
939\end{array}$ & $11,577,231,910$ & $95,348,572,123$ \\
\hline Operation Ratio & 0.008274487 & 0.003085957 & 0.001172399 \\
\hline
\end{tabular}

Source: Data processed 2021

In terms of profit margin or profit margin, it shows that operating profit related to sales has increased, profit margin has decreased in 2019 by $0.001 \%(0.0188-0.0189)$ but in 2020 it has increased by $0.003 \%$ Decrease in sales in 2019 caused by delayed delivery of products or goods to consumers. The delay occurred due to the lack of maintenance of transportation equipment and the lack of discipline of employees at the Sungai Penuh Jambi City Drinking Water Company (PDAM). Thus, the profit margin for the Regional Water Supply Company of Sungai Penuh Jambi City is considered less good.

2. Measuring Performance Based on Customer Perspective

a. New Customer Acquisition Rate (Customer Acquisition)

Assessment based on Customer Acquisition can be seen in the following table;

Table 5.Assessment based on Customer Acquisition can be seen in the following table;

\begin{tabular}{|l|c|c|c|}
\hline Financial Perspective & $\mathbf{2 0 1 8}$ & $\mathbf{2 0 1 9}$ & $\mathbf{2 0 2 0}$ \\
\hline Number of new & 3,190 & 3,320 & 3.415 \\
\hline
\end{tabular}




\begin{tabular}{|l|c|c|c|}
\hline subscribers & & & \\
\hline $\begin{array}{l}\text { Total number of } \\
\text { customers }\end{array}$ & 33554 & 35031 & 35439 \\
\hline Acquisition Customer & $9.5 \%$ & $9.4 \%$ & $9.6 \%$ \\
\hline
\end{tabular}

Source: Data processed 2021

Based on the measurement of the company's success in attracting new customers in the Regional Water Company (PDAM) Sungai Penuh Jambi decreased. This is because customers feel the impact of the economic crisis caused by the pandemic situation, and that service and delivery of goods takes a long time. It can be concluded that the Sungai Penuh Jambi Regional Drinking Water Company (PDAM) in acquiring new customers is considered not good.

\section{b. Customer retention rate / ability to retain old(customers retention)}

Assessment based on customer retention can be seen in the following table;

Table 6. Assessment based on customer retention can be seen in the following table;

\begin{tabular}{|l|c|c|c|}
\hline Financial Perspective & $\mathbf{2 0 1 8}$ & $\mathbf{2 0 1 9}$ & $\mathbf{2 0 2 0}$ \\
\hline $\begin{array}{l}\text { Total Existing } \\
\text { customers }\end{array}$ & 33235 & 34699 & 32024 \\
\hline TotalTotal customer & 33554 & 35031 & 35439 \\
\hline retention Customer & $99.04 \%$ & $99.05 \%$ & $90.36 \%$ \\
\hline
\end{tabular}

Source: Data processed 2021

Results calculated using the formula customer Acquisition with the percentage of the company's ability to retain existing customers it can be said that it is not good in 2019 to 2020, so the ability to retain old customers at the Sungai Penuh Jambi City Drinking Water Company (PDAM) can be said to be fluctuating in the assessment of the percentage of customer acquisition. The company is expected to retain old customers and increase the number of new customers by paying attention to customer service.

\section{c. Level of customer satisfaction (customer satisfaction)}

Assessment based on customer satisfaction can be seen in the following table;

Table 7. Assessment based on customer retention can be seen in the following table;

\begin{tabular}{|l|c|c|c|}
\hline Financial Perspective & $\mathbf{2 0 1 8}$ & $\mathbf{2 0 1 9}$ & $\mathbf{2 0 2 0}$ \\
\hline $\begin{array}{l}\text { Total Existing } \\
\text { customers }\end{array}$ & 33235 & 34699 & 32024 \\
\hline TotalTotal customer & 33554 & 35031 & 35439 \\
\hline retention Customer & $99.04 \%$ & $99.05 \%$ & $90.36 \%$ \\
\hline
\end{tabular}

Source: Data processed 2021

Based on the level of customer satisfaction is measured On Regional Water Company (PDAM) Sungai Penuh Jambi there is a decrease in satisfaction from 2019 to 2020. In customer satisfaction, it can also be seen from the evaluation of the results that it is concluded that the Regional Drinking Water Company (PDAM) of Sungai Penuh Jambi City in 2020 can be said to be less good. 


\section{Performance Based on Internal Business Process Perspective}

Seen from the internal business perspective, it is measured using four variables, namely, (1) motivation (2) power (3) alignment and (4) Internal Business Process Perspective using a sample of 50 employees, the following results were found; Table 8. Relationship Perspective Internal Business Process Regional Water Company

(PDAM) Kota Sungai Penuh Jambi

\begin{tabular}{|c|c|c|c|c|c|c|}
\hline & Item & Motivation & Power & Alignment & $\begin{array}{c}\text { Process } \\
\text { Perspective I } \\
\text { nternal } \\
\text { Business } \\
\end{array}$ & Description \\
\hline $\begin{array}{l}\text { Motivation } \\
\text { Power of }\end{array}$ & $\begin{array}{l}\text { Pearson's Correlation } \\
\text { Sig. (2-tailed) N } \\
\text { Pearson } \\
\text { Correlation } \\
\text { Sig. (2-tailed) }\end{array}$ & 50 & $\begin{array}{r}.218 \\
.128 \\
50\end{array}$ & $\begin{array}{r}.218 \\
.128 \\
50\end{array}$ & $\begin{array}{r}.667^{* *} \\
.000 \\
50\end{array}$ & Valid \\
\hline Alignment & \begin{tabular}{|l} 
N \\
Pearson \\
Correlation \\
Sig. (2-tailed)
\end{tabular} & $\begin{array}{r}.218 \\
.128 \\
50\end{array}$ & 1 & $\begin{array}{r}1.000^{* *} \\
.000 \\
50\end{array}$ & $\begin{array}{r}.509^{* *} \\
.000 \\
50\end{array}$ & Valid \\
\hline $\begin{array}{l}\text { Perspective } \\
\text { Business } \\
\text { process Internal } \\
\text { Motivation }\end{array}$ & \begin{tabular}{|l}
$\mathrm{N}$ \\
Pearson \\
Correlation \\
Sig. (2-tailed) N \\
Pearson's \\
Correlation \\
Sig. (2-tailed) N \\
\end{tabular} & .218 & $\begin{array}{r}1.000^{* *} \\
.000\end{array}$ & 50 & $.509^{* *}$ & Valid \\
\hline Power of & $\begin{array}{l}\text { Pearson } \\
\text { Correlation } \\
\text { Sig. (2-tailed) } \\
\text { N }\end{array}$ & $\begin{array}{r}.667^{* *} \\
.000 \\
50\end{array}$ & $\begin{array}{r}.509^{* *} \\
.000 \\
50\end{array}$ & $\begin{array}{r}.509^{* *} \\
.000 \\
50\end{array}$ & 50 & \\
\hline
\end{tabular}

**. Correlation is significant at the 0.01 level (2-tailed).

From table 8 above it can be concluded that;

1) Work motivation has an effect on the performance of the Regional Drinking Water Company (PDAM) Tirta Dharma, Sungai Penuh Jambi City, which has an influence level of $66.7 \%$ with a significance level of $<5 \%$ or $0 \%$.

2) Power affects the performance of the Regional Drinking Water Company (PDAM) of Sungai Penuh Jambi City which has an influence level of $50.9 \%$ with a significance level of $<5 \%$ or $0 \%$.

3) Alignment affects the performance of the Regional Drinking Water Company (PDAM) in Sungai Penuh Jambi City which has an influence level of 50.9\% with a significance level of $<5 \%$ or $0 \%$.

4) Performance based on internal business perspective through learning and growth by conducting trainings for 50 employees shows the results in the first training have a relationship of $59 \%$ with a significance level below $5 \%$ or $0 \%$, in the second training it has a relationship of $66.7 \%$ with significance level below $5 \%$ or $0 \%$, in the 
third training. It has relationships of $81.6 \%$ with a significance level below $5 \%$ or $0 \%$, in the fourth training. It has a relationship of $25 \%$ with a significance level below $5 \%$ or equal to $0 \%$ and in the fifth training, there is a relationship of $100 \%$ with a significance level below $5 \%$ or $0 \%$.

\section{Performance Based on Learning and Growth Perspective}

\section{a. Employee satisfaction}

Calculation of the results of employee satisfaction at the Regional Water Company (PDAM) Sungai Penuh Jambi has implemented training and learning for employees, but there are still shortcomings, namely the length of time training and learning are held or employee training and learning are held. This is because the company focuses on the production process and generates profits which has an impact on the lack of attention to employees in learning and training. It is expected that the company at the Regional Drinking Water Company (PDAM) of Sungai Penuh Jambi City will further increase the training and learning time of employees. Training should be held 3 (three) times a year.

\section{b. Employee retention Employee}

Retention at the Regional Drinking Water Company (PDAM) of Sungai Penuh Jambi City has implemented training and learning for employees, but there are still shortcomings, namely the length of time for training and learning is held or employee training and learning is held. Because the company focuses on the production process and generate profits. And the impact of lack of attention to employees in learning and training. It is hoped that the company at the Regional Drinking Water Company (PDAM) of Sungai Penuh Jambi City will further increase the training and learning time of employees in the future.

\section{c. Productivity}

The results of employee productivity are calculated in rupiah, not using the percentage increase at the Regional Water Company (PDAM) of Sungai Penuh Jambi City, so that it has increased from year to year. Productivity increased due to the increase in product sales from every year. Which has an impact on net income and also increases when calculating the profitability formula, which increases every year. Increased productivity will make a positive contribution to improving the company's economy.

\section{CONCLUSION}

The results of performance measurement using the approach Balanced Score Card at PDAM Kota Sungai Penuh Jambi from a Financial Perspective on the Current Ratio (CR) that the capital capacity invested in the Regional Water Company of Sungai Penuh Jambi City can be said to be good. Assessment based on the profit margin of profit that PDAM Kota Sungai Penuh Jambi is considered unfavorable due to a decline in sales in 2019 , the delivery of products or goods to consumers who experience delays. The delay occurred due to the lack of maintenance of transportation 
equipment and the lack of discipline of employees at the Sungai Penuh Jambi City Drinking Water Company (PDAM). The assessment is based on the Operating Ratio that there was a decline in sales in 2019 due to arrears in payments from the consumer but there was an increase again in 2020, the assessment based on the Operating Ratio can be said to be good. Assessment based on Return On Investment, the assessment based on Return On Investment can be said to be good. The results of performance measurement approach Balanced Score Card in PDAM Sungai Penuh Jambi on customer perspective to the acquisition level Acquisition customer in the Regional Water Company (PDAM) Sungai Penuh Jambi experience the value of percentage increase in the acquire new customers despite a decline in 2019.

Ratings based on customer retention, it is expected to be able to retain old customers and increase the number of new customers by paying attention to customer service due to a sharp decline in customer retention in 2020. The assessment based on customer satisfaction shows that the Sungai Penuh Jambi City Regional Drinking Water Company (PDAM) in 2020 can be said to be lacking good. The results of performance measurement with the approach Balanced Score Card at PDAM Kota Sungai Penuh Jambi are based on the Internal Business Process Perspective that (1) motivation (2) power (3) alignment has a significant effect on the company's internal business processes. The results of performance measurement with the approach Balanced Score Card at PDAM Kota Sungai Penuh Jambi Based on the Learning and Growth Perspective, it is expected that the company at the Regional Drinking Water Company (PDAM) of Sungai Penuh Jambi City will further increase employee training and learning time. Training should be held 3 (three) times a year. Employee retention at the Regional Drinking Water Company (PDAM) of Sungai Penuh Jambi City has implemented training and learning for employees, but there are still shortcomings, namely the length of time for training and learning is held or employee training and learning is held. The results of employee productivity have increased from year to year. The results of our research that performance measurement at PDAM Kota Sungai Penuh Jambi is in line with research by Kaplan et al, (2010) that the Balanced Scorecard can be used as a tool for decision making and the Balanced Scorecard can help public companies in controlling finances and measuring company performance.

\section{ACKNOWLEDGMENTS}

The authors are grateful to the Regional Drinking Water Company in Sungai

Penuh Jambi city for helping us in this research. Thank you to all the lecturers who have been involved in writing this article. I hope this article is useful for readers.

\section{REFERENCES}

[1] Giri, Efraim Ferdinan. 1998. "Balanced Scorecard : Suatu Sistem Pengukuran Kinerja Strategik". Kajian Bisnis, No.13, 35-46. 
[2] Helfert, A, Erich. 2014. Teknis Analisis Keuangan: Petunjuk Praktik untuk Mengelola dan Mengukur Kinerja Perusahaan. Jakarta: PT Elex Media Komputindo.

[3] Kaplan, Robert S and David P Norton, 2010. Balanced Scorecard : Menerapkan Strategi Menjadi Aksi. Jakarta: Erlangga.

[4] Kaplan, R. dan D. Norton. 1996. Balanced Scorecard : Menerapkan Strategi Menjadi Aksi. Erlangga : Jakarta.

[5] Kaplan, R. dan D. Norton. 2000. Balanced Scorecard : Menerapkan Strategi Menjadi Aksi, Terjemahan oleh Peter R. Yosi Pasla dari Balanced Scorecard : Transalting Strategy Into Action (1996). Erlangga : Jakarta. Mangkunegara, A. Anwar Prabu. 2012. Evaluasi Kinerja. Jakarta: Refika Aditama.

[6] Mulyadi dan Setyawan Jhony. 2010. Sistem Perencanaan dan Pengenalian Manajemen Edisi Ke-2. Jakarta: Salemba Empat.

[7] Rai, I Gusti Agung. 2018. Audit Kinerja pada Sektor Publik: Konsep praktik studi kasus. Jakarta: Salemba empat.

[8] Sugiyono. 2011. Metode Penelitian Kuantitatif, Kualitatif dan R\&D. Bandung: Afabeta.

[9] Srimindarti, Ceacilia. 2014. "Balanced Score Card sebagai Alternatif untuk mengukur kinerja". Fokus Ekonomi, Vol 3 No 1.

[10] Warindrani, Armila Krisna. 2016. Akuntansi Manajemen. Jogjakarta: Graha Ilmu.

[11] Waskita, J. dan M. T. Purwanto. 2012. "Analisis Penilaian Kinerja Organisasi dengan Menggunakan Konsep Balanced Scorecard Pada PD. BPR BKK Banjarharjo”. Jurnal Penilaian Kinerja Akuntansi, Vol. 3, No. 